\title{
ANALISIS PENERAPAN HARGA POKOK PRODUKSI PADA USAHA MIKRO KECIL DAN MENENGAH (UMKM) PABRIK ROTI TAENG DI GOWA
}

\author{
Daryanti $^{1}$, Neng Indriyani ${ }^{2}$ \\ Prodi Akuntansi, STIE YPUP Makassar \\ Email: daryanti0508@gmail.com, nengindriyani16@gmail.com
}

\begin{abstract}
This research was conducted with the aim of knowing the application of the cost of production carried out by the Micro, Small and Medium Enterprise (UMKM) Taeng Bakery Factory in Gowa. This is important considering that the calculation of the exact and detailed cost of products is needed as a basis in determining the right selling price to increase the company's income (profit). Taeng Bakery Factory is one of the business activities that in applying the cost of production still uses a simple method. In this study, the calculation of cost of production uses the full costing method. The analysis used is descriptive and comparative method. Production costs are calculated based on estimates. In addition, the company does not account for factory overhead costs such as depreciation of machinery and equipment into production costs.
\end{abstract}

Keywords: Cost Of Production, Full Costing Method

\begin{abstract}
Abstrak
Penelitian ini dilakukan dengan tujuan untuk mengetahui penerapan harga pokok produksi yang dilakukan oleh Usaha Mikro Kecil Menengah (UMKM) Pabrik Roti Taeng di Gowa. Hal ini penting mengingat penghitungan harga pokok produk yang tepat dan rinci diperlukan sebagai dasar dalam menentukan harga jual yang tepat untuk meningkatkan pendapatan (laba) perusahaan. Pabrik Roti Taeng merupakan salah satu kegiatan usaha yang dalam penerapan harga pokok produksinya masih menggunakan metode yang sederhana. Dalam penelitian ini penghitungan harga pokok produksi menggunakan metode full costing. Analisis data yang digunakan adalah metode deskriptif dan komparatif. Biaya produksi dihitung berdasarkan perkiraan. Selain itu, perusahaan tidak memperhitungkan biaya overhead pabrik tetap seperti penyusutan mesin dan peralatan menjadi biaya produksi.
\end{abstract}

Kata Kunci: Harga Pokok Produksi, Metode Full Costing

PENDAHULUAN

Latar belakang

Usaha Mikro, Usaha Kecil dan Usaha Menengah adalah suatu pilar utama ekonomi nasional yang harus memperoleh kesempatan utama, dukungan, perlindungan, dan pengembangan seluas-luasnya sebagai wujud keberpihakan yang tegas kepada 
usaha ekonomi rakyat, seperti halnya pada aktivitas utama industri rumahan dan kelompok usaha bersama dengan tidak mengabaikan peranan usaha besar dan Badan Usaha Milik Negara.

Pada umumnya perusahaan menciptakan atau menyediakan barang ataupun jasa dengan tujuan untuk memperoleh keuntungan (laba) seoptimal mungkin dan memberikan kepuasan bagi para pelanggan (konsumen). Untuk mencapai tujuan tersebut, para pelaku usaha dituntut mampu menciptakan atau menyediakan barang ataupun jasa yang berkualitas dengan harga jual yang kompetitif. Untuk itu diperlukan perhitungan harga pokok produk yang tepat dan rinci sebagai dasar dalam penetapan harga jual produk.

Menurut Sujarweni (2015:3) harga pokok produk digunakan perusahaan untuk menentukan besarnya laba yang diperoleh dan juga untuk menentukan harga jual. Penetapan harga jual yang tepat membantu perusahaan untuk memperoleh laba sesuai target yang diinginkan.

Pabrik roti taeng merupakan salah satu UMKM yang memproduksi produknya secara mandiri mulai dari penyediaan bahan baku sampai produk siap dijual. Sehingga, perhitungan harga pokok produk menjadi suatu hal yang penting untuk menentukan harga jual produk di pasaran. Berdasarkan latar belakang tersebut, sehingga peneliti tertarik untuk mengetahui penerapan harga pokok produksi yang dilakukan oleh UMKM pabrik roti taeng di Gowa.

\section{TINJAUAN PUSTAKA Pengertian Biaya}

Menurut Sofia P. Dewi dan Septian B. Kristanto (2017:10) menjelaskan biaya adalah sumber daya yang dikorbankan atau dilepaskan untuk mencapai tujuan tertentu di masa depan.

Selanjutnya biaya menurut Sujarweni (2015:9) mempunyai dua pengertian secara luas dan secara sempit. Biaya dalam arti luas adalah pengorbanan sumber ekonomi yang diukur dalam satuan uang dalam usahanya untuk mendapatkan sesuatu untuk mencapai tujuan tertentu baik yang sudah terjadi dan belum terjadi/ baru direncanakan. Biaya dalam arti sempit adalah pengorbanan sumber ekonomi dalam satuan uang untuk memperoleh aktiva.

Biaya digolongkan dengan berbagai macam cara. Umumnya penggolongan biaya ini ditentukan atas dasar tujuan yang hendak dicapai dengan penggolongan tersebut.

\section{Metode Pengumpulan Biaya Produksi}

Menurut Hansen dan Mowen (2013:56) biaya dikelompokkan dalam dua kategori fungsional utama:

1. Biaya produksi adalah biaya yang berkaitan dengan pembuatan barang dan penyediaan jasa.

2. Biaya nonproduksi adalah biaya yang berkaitan dengan fungsi desain, pengembangan, pemasaran, distribusi, layanan pelanggan, dan administrasi umum.

\section{Pengertian Harga Pokok Produksi}


Bustami dan Nurlela (2013:49) harga pokok produksi adalah kumpulan biaya produksi yang terdiri dari bahan baku langsung, tenaga kerja langsung dan biaya overhead pabrik ditambah persediaan produk dalam proses awal dan dikurangi persediaan produk dalam proses akhir. Harga pokok produksi terikat pada periode waktu tertentu. Harga pokok produksi akan sama dengan biaya produksi apabila tidak ada persediaan produk dalam proses awal dan akhir.

Sofia P. Dewi dan Septian B. Kristanto (2017:21) biaya produksi dapat digolongkan menjadi tiga yaitu: Biaya Bahan Baku, Biaya Tenaga Kerja Langsung, Biaya Overhead Pabrik

\section{Penentuan Harga Pokok Produksi}

Menurut Mulyadi (2014:17) metode penentuan kos produksi adalah cara memperhitungkan unsur-unsur biaya ke dalam kos produksi. Dalam memperhitungkan unsur-unsur biaya ke dalam kos produksi, terdapat dua pendekatan yaitu:

1. Metode Biaya Penuh (Full Costing).

Full costing atau sering pula disebut absorption atau conventional costing adalah metode penentuan harga pokok produksi yang membebankan seluruh biaya produksi, baik yang berperilaku tetap maupun variabel kepada produk.

2. Metode Biaya Variabel (Variable Costing)

Variable costing adalah metode penentuan harga pokok produksi yang hanya membebankan biaya-biaya produksi variabel saja ke dalam harga pokok produk.

\section{Laporan Harga Pokok Produksi}

Laporan harga pokok produksi disusun untuk setiap produksi berlangsung, pada umumnya laporan harga pokok produksi berisi tiga laporan, yaitu:

1. Laporan Produksi (Skedul Kuantitas)

2. Pembebanan Biaya

3. Perhitungan Biaya

\section{METODE PENELITIAN}

Penelitian ini dilakukan dengan menggunakan teknik pengumpulan data metode wawancara dan dokumentasi, yaitu metode yang digunakan dengan mengumpulkan, mencatat, dan melakukan pengkajian data, baik yang bersifat kualitatif maupun kuantitatif yang berupa informasi tentang perusahaan dan laporan sehubungan dengan biaya produksi. Adapun metode yang digunakan dalam menganalisis data ialah metode deskriptif komparatif dimana melakukan perbandingan antara perhitungan biaya menurut perusahaan dengan metode full costing.

\section{HASIL DAN PEMBAHASAN}

\section{Elemen Harga Pokok Produksi Perusahaan}

Elemen biaya untuk menentukan harga pokok produksi adalah biaya langsung dan biaya tidak langsung yang digunakan perusahaan dalam proses produksi roti. Dalam perhitungan harga pokok produksi, perusahaan masih menggunakan perhitungan sederhana yaitu dengan menambah seluruh biaya yang dianggap berpengaruh terhadap proses produksi roti. Hasil perhitungan ini kemudian digunakan perusahaan untuk menentukan harga jual dengan tingkat keuntungan yang diinginkan perusahaan untuk setiap jenis roti yang diproduksi. Komponen biaya yang digunakan perusahaan dalam memproduksi roti, yaitu sebagai berikut: 


\section{AkMen}

Volume 17 Nomor 4 Desember 2020

Hal. 630 - 640

e-ISSN : 2621-4377 \& p-ISSN : 1829-8524

Hbmepage: https//e-jurnalstiendbel-indonesiaacid/indexphp/akmen

\section{a. Biaya Bahan Baku}

Biaya bahan baku adalah seluruh biaya yang dikeluarkan perusahaan untuk memperoleh bahan baku. Perusahaan tidak memperhitungkan biaya angkut pembelian, hal ini dikarenakan biaya angkut pembelian ditanggung oleh pemasok bahan baku.

Tabel 1. Biaya Bahan Baku Perusahaan Selama Satu Bulan

\begin{tabular}{|l|c|c|c|}
\hline $\begin{array}{l}\text { Nama } \\
\text { Bahan }\end{array}$ & $\begin{array}{c}\text { Biaya } \\
\text { Bahan Baku } \\
\text { (A) }\end{array}$ & $\begin{array}{c}\text { Asumsi } \\
\text { Jumlah } \\
\text { Produksi } \\
\text { (B) }\end{array}$ & $\begin{array}{c}\text { Biaya } \\
\text { Bahan } \\
\text { Baku } \\
\text { per pcs } \\
\text { (A:B) }\end{array}$ \\
\hline $\begin{array}{l}\text { Roti } \\
\text { Tawar }\end{array}$ & 70.252 .000 & 26.000 & 2.702 \\
\hline $\begin{array}{l}\text { Roti } \\
\text { Manis }\end{array}$ & 80.600 .000 & 26.000 & 3.100 \\
\hline
\end{tabular}

Sumber: CV. Taeng Jaya Mandiri

Berdasarkan data dan informasi yang diperoleh peneliti, dalam memperhitungkan biaya bahan baku untuk setiap unit produk, perusahaan mengasumsikan jumlah produksi sebanyak 1.000 pcs untuk setiap jenis roti (roti tawar dan roti manis) setiap harinya, dengan demikian produksi roti selama satu bulan diasumsikan sebanyak 26.000 pcs (1.000 x 26 hari) untuk setiap jenis roti. Hal ini tidak sesuai dengan biaya yang sesungguhnya dikeluarkan, karena berdasarkan data dan informasi yang diperoleh dari pabrik, produksi yang dilakukan setiap harinya adalah \pm 1.000 pcs untuk kedua jenis roti tersebut, yaitu 810 pcs roti tawar dan sekitar 108 pcs untuk roti manis. Dengan demikian biaya bahan baku harus dihitung berdasarkan jumlah unit produksi yang dihasilkan.

\section{b. Biaya Tenaga Kerja}

Perusahaan menggolongkan biaya tenaga kerja ke dalam gaji karyawan (langsung maupun tidak langsung) bersama dengan memasukkan biaya operasional kendaraan dan biaya catering. Berikut rincian biaya gaji karyawan perusahaan:

Tabel 2. Biaya Gaji Karyawan Perusahaan

\begin{tabular}{|l|r|r|}
\hline Biaya & $\begin{array}{c}\text { Per Hari } \\
\text { (Rp) }\end{array}$ & \multicolumn{1}{c|}{$\begin{array}{c}\text { Per Bulan } \\
(\text { Rp) }\end{array}$} \\
\hline $\begin{array}{l}\text { Gaji } \\
\text { Karyawan }\end{array}$ & 944.230 & 24.550 .000 \\
\hline $\begin{array}{l}\text { Operasional } \\
\text { Kendaraan }\end{array}$ & 220.000 & 5.720 .000 \\
\hline Catering & 120.000 & 3.120 .000 \\
\hline \multicolumn{1}{|c|}{ Total } & $\mathbf{1 . 2 8 4 . 2 3 0}$ & $\mathbf{3 3 . 3 9 0 . 0 0 0}$ \\
\hline
\end{tabular}

\section{c. Biaya Overhead Pabrik}

Sumber: CV. Taeng Jaya Mandiri

Berdasarkan data yang diperoleh, biaya overhead pabrik perusahaan antara lain berupa biaya listrik, biaya gas LPG, biaya plastik packing, dan biaya tenaga packing.

1) Biaya listrik. Dalam proses produksi, biaya listrik yang digunakan diperkirakan sebesar Rp 1.170.000,- per bulan. 
2) Biaya LPG. Dalam proses produksi, perusahaan menggunakan gas LPG ukuran 3 $\mathrm{kg}$. Dalam 1x produksi perusahaan akan menghabiskan 8 tabung gas. Dengan demikian, dalam satu bulan perusahaan akan menghabiskan 208 tabung gas $(8 \mathrm{x}$ 26 hari) Perusahaan membeli LPG (3 kg) dengan harga $\mathrm{Rp} 18.000$,- per tabungnya. Biaya gas LPG dihitung sebesar Rp 3.744.000,- per bulannya

3) Biaya plastik packing. Dalam pengemasan produk, perusahaan menggunakan dua jenis kemasan plastik, yaitu untuk kemasan roti tawar dengan harga Rp 325,- per lembarnya dan untuk roti manis dengan harga $\mathrm{Rp} 450$,- per lembarnya. Data biaya kemasan dapat diperkirakan sebesar Rp. 20.150.000,- dimana untuk packing roti tawar sebesar Rp. 8.450.000,- (325.000 x 26) dan untuk roti manis sebesar Rp. $11.700 .000,-(450.000 \times 26)$.

4) Biaya Tenaga Packing. Perusahaan mengeluarkan biaya tenaga packing sebesar Rp 100.000,- per hari atau sebesar Rp 2.600.000,- per bulannya. Berdasarkan teori yang mendukung penelitian ini, biaya tenaga packing ini seharusnya dimasukkan ke dalam biaya tenaga kerja langsung.

\section{Harga Pokok Produksi Perusahaan}

Perhitungan harga pokok produksi dapat dilihat pada tabel berikut :

Tabel 3. Perhitungan Harga Pokok Produksi Roti Tawar Metode Perusahaan

\begin{tabular}{|c|c|}
\hline Jenis Biaya & Total Biaya (Rp) \\
\hline Biaya Bahan Baku & $70.252 .000,-$ \\
\hline Biaya Tenaga Kerja & 33.390.000,- \\
\hline \multicolumn{2}{|l|}{ Biaya Overhead Pabrik: } \\
\hline Biaya Listrik & $1.170 .000,-$ \\
\hline Biaya Gas LPG & $3.744 .000,-$ \\
\hline Biaya Plastik Packing & $8.450 .000,-$ \\
\hline Biaya Tenaga Packing & $2.600 .000,-$ \\
\hline Total Biaya Overhead Pabrik & $15.964 .000,-$ \\
\hline Total Biaya Produksi & $119.606 .000,-$ \\
\hline Jumlah Produksi & $26.000 \mathrm{pes}$ \\
\hline Harga Pokok Produksi per pes & 4.600 . \\
\hline
\end{tabular}

Tabel 4. Perhitungan Harga Pokok Produksi Roti Manis Metode Perusahaan

\begin{tabular}{|l|r|}
\hline \multicolumn{1}{|c|}{ Jenis Biaya } & \multicolumn{2}{c|}{ Total Biaya (Rp) } \\
\hline Biaya Bahan Baku & $\mathbf{8 0 . 6 0 0 . 0 0 0 , -}$ \\
\hline Biaya Tenaga Kerja & $\mathbf{3 3 . 3 9 0 . 0 0 0 , -}$ \\
\hline Biaya Overhead Pabrik: & $1.170 .000,-$ \\
\hline Biaya Listrik & $3.744 .000,-$ \\
\hline Biaya Gas LPG & $11.700 .000,--$ \\
\hline Biaya Plastik Packing & $2.600 .000,-$ \\
\hline Biaya Tenaga Packing & $\mathbf{1 9 . 2 1 4 . 0 0 0 , -}$ \\
\hline Total Biaya Overhead Pabrik & $\mathbf{1 3 3 . 2 0 4 . 0 0 0 , -}$ \\
\hline Total Biaya Produksi & $\mathbf{2 6 . 0 0 0} \mathbf{~ p c s}$ \\
\hline Jumlah Produksi & \\
\hline Harga Pokok Produksi per pcs & $\mathbf{5 . 1 2 3 , -}$ \\
\hline Sumber: CV. Taeng Jaya Mandiri & \\
\hline
\end{tabular}

\section{Elemen Harga Pokok Produksi menurut Metode Full Costing}


Dalam metode full costing, semua biaya produksi baik yang berperilaku variabel maupun tetap diperhitungkan. Komponen biaya menurut metode full costing yaitu sebagai berikut:

\section{a. Biaya Bahan Baku}

Biaya bahan baku dalam metode full costing memperhitungkan seluruh biaya yang terkait dengan pemerolehan bahan baku, termasuk biaya angkut pembelian bahan baku.

Tabel 5. Biaya Bahan Baku

(Full costing)

Selama Satu Bulan

\begin{tabular}{|l|c|c|c|}
\hline $\begin{array}{l}\text { Nama } \\
\text { Bahan }\end{array}$ & $\begin{array}{c}\text { Biaya } \\
\text { Bahan Baku } \\
\text { (A) }\end{array}$ & $\begin{array}{c}\text { Jumlah } \\
\text { Produksi } \\
\text { (B) }\end{array}$ & $\begin{array}{c}\text { Biaya } \\
\text { Bahan } \\
\text { Baku } \\
\text { per pcs } \\
\text { (A:B) }\end{array}$ \\
\hline $\begin{array}{l}\text { Roti } \\
\text { Tawar }\end{array}$ & 63.492 .577 & 21.060 & 3.015 \\
\hline $\begin{array}{l}\text { Roti } \\
\text { Manis }\end{array}$ & 10.398 .987 & 2.808 & 3.703 \\
\hline
\end{tabular}

Sumber: Data diolah

\section{b. Biaya Tenaga Kerja}

Biaya tenaga kerja langsung CV. Taeng Jaya Mandiri terdiri dari biaya tenaga produksi dan biaya tenaga packing.

\section{Tabel 6. Biaya Tenaga Kerja}

(Full costing)

Selama satu bulan

\begin{tabular}{|c|c|c|c|c|c|}
\hline Biaya & \begin{tabular}{|l|} 
Jumlah \\
(orang)
\end{tabular} & $\begin{array}{c}\text { Per Hari } \\
\text { (Rp) }\end{array}$ & $\begin{array}{c}\text { Per } \\
\text { Minggu }\end{array}$ & Jumlah & $\begin{array}{c}\text { Per Bulan } \\
\text { (Rp) }\end{array}$ \\
\hline $\begin{array}{c}\text { Tenaga } \\
\text { Produksi }\end{array}$ & 8 & - & $425.000,-$ & 3.400 .000 & 13.600.000,- \\
\hline $\begin{array}{c}\text { Tenaga } \\
\text { Packing } \\
\end{array}$ & 1 & 100.000,- & - & 100.000 & 2.600 .000 ,- \\
\hline \multicolumn{5}{|c|}{ Total } & 16.200.000,- \\
\hline
\end{tabular}

Tabel 7. Alokasi Biaya Tenaga Kerja (Full costing)

Ke masing-masing produk

\begin{tabular}{|c|c|c|c|c|c|}
\hline \multirow{2}{*}{ Ket. } & \multirow{2}{*}{$\begin{array}{c}\text { Jumlah } \\
\text { Produksi }\end{array}$} & \multirow{2}{*}{$\begin{array}{c}\% \\
\text { Alokasi } \\
\text { Biaya }\end{array}$} & \multicolumn{2}{|c|}{$\begin{array}{c}\text { Alokasi Biaya } \\
\text { (Rp) }\end{array}$} & \multirow{2}{*}{ Total } \\
\hline & & & $\begin{array}{c}\text { Tenaga } \\
\text { Produksi }\end{array}$ & $\begin{array}{r}\text { Tenaga } \\
\text { Packing }\end{array}$ & \\
\hline $\begin{array}{l}\text { Roti } \\
\text { Tawar }\end{array}$ & 21.06 & $88 \%$ & 11.968.000, & 2.288.000,- & 14.256.000, \\
\hline $\begin{array}{l}\text { Roti } \\
\text { Manis }\end{array}$ & 2.808 & $12 \%$ & $1.632 .000,-$ & 312.000 ,- & 1.944.000, \\
\hline Total & 23.868 & $100 \%$ & 13.600.000, & 2.600.000,- & 16.200 .000 \\
\hline
\end{tabular}

\section{c. Biaya Overhead Pabrik}

Biaya-biaya yang diabaikan perusahaan adalah biaya penyusutan mesin dan peralatan serta biaya pemeliharaan mesin dan peralatan. Setelah menghitung biaya penyusutan mesin dan peralatan, maka didapatkan biaya penyusutan mesin dan 
peralatan per bulan itu sebesar Rp. 2.243.750,-. Adapun biaya pemeliharaan mesin dan peralatan masuk dalam kategori biaya overhead pabrik dengan estimasi biaya sebesar Rp. 150.000,- setiap bulan.

Aktualisasi pemakaian biaya plastik selama sebulan dengan menggunakan metode full costing.

Tabel 8. Biaya Plastik Packing

(Full costing)

Selama satu bulan

\begin{tabular}{|l|r|r|c|}
\hline Ket. & Jumlah Produksi & $\begin{array}{c}\text { Harga Satuan } \\
\text { (Rp) }\end{array}$ & Jumlah \\
\hline $\begin{array}{l}\text { Roti } \\
\text { Tawar }\end{array}$ & $21.060 \mathrm{pcs}$ & $325,-$ & $6.844 .500,-$ \\
\hline $\begin{array}{l}\text { Roti } \\
\text { Manis }\end{array}$ & $2.808 \mathrm{pcs}$ & $450,-$ & $1.263 .200,-$ \\
\hline \multicolumn{3}{|c|}{ Total } & $\mathbf{8 . 1 0 7 . 7 0 0 , -}$ \\
\hline
\end{tabular}

Tabel 9. Evaluasi Biaya Overhead Pabrik

\begin{tabular}{|l|r|}
\multicolumn{1}{|c|}{$\left(\begin{array}{c}\text { Biaya } \begin{array}{c}\text { Overhead } \\
\text { Pabrik }\end{array} \\
\text { Biaya Listrik }\end{array}\right.$} & Total Biaya (Rp) \\
\hline Biaya Gas LPG & $3.170 .000,-$ \\
\hline Biaya Plastik Packing & $8.107 .700,-$ \\
\hline $\begin{array}{l}\text { Biaya Penyusutan } \\
\text { Mesin dan Peralatan }\end{array}$ & $2.243 .750,-$ \\
\hline $\begin{array}{l}\text { Biaya Pemeliharaan } \\
\text { Mesin dan Peralatan }\end{array}$ & $\mathbf{1 5 0 . 0 0 0 , -}$ \\
\hline \multicolumn{1}{|c|}{ Total } & $\mathbf{1 5 . 4 1 5 . 4 5 0 , -}$ \\
\hline Sumber: Data diolah & \\
\hline
\end{tabular}

Tabel 10. Alokasi Biaya Overhead Pabrik (Full costing) Ke masing-masing produk 


\begin{tabular}{|c|c|c|c|}
\hline Keterangan & Biaya & $\begin{array}{c}\text { Alokasi } \\
\text { Biaya Roti } \\
\text { Tawar } \\
(\mathbf{8 8 \%}) \\
(\mathbf{R p})\end{array}$ & \begin{tabular}{|c|} 
Alokasi \\
Biaya Roti \\
Manis \\
$(12 \%)$ \\
(Rp)
\end{tabular} \\
\hline \multicolumn{4}{|c|}{ Biay a Overhead Pabrik Variabel: } \\
\hline Biay a Listrik & $1.170 .000,-$ & $1.029 .600,-$ & 140.400,- \\
\hline Biaya Gas LPG & $3.744 .000,-$ & $3.294 .720,-$ & $449.280,-$ \\
\hline Biay a Plastik Packing & $8.107 .700,-$ & $6.844 .500,-$ & $1.263 .200,-$ \\
\hline \multicolumn{4}{|c|}{ Biay a Overhead Pabrik Tetap: } \\
\hline \multicolumn{4}{|l|}{ Biay a Peny usutan: } \\
\hline Oven Listrik & $562.500,-$ & $495.000,-$ & $67.500,-$ \\
\hline Oven Manual & $300.000,-$ & $264.000,-$ & $36.000,-$ \\
\hline Mixer & $437.500,-$ & $385.000,-$ & $52.500,-$ \\
\hline Alat Pemotong & $218.750,-$ & $192.500,-$ & $26.250,-$ \\
\hline Talang1 & $195.000,-$ & $171.600,-$ & $23.400,-$ \\
\hline Talang2 & $80.000,-$ & $70.400,-$ & $9.600,-$ \\
\hline Mesin Kupas & $116.666,-$ & $102.666,-$ & $14.000,-$ \\
\hline Proofin & 166.667,-- & $146.667,-$ & $20.000,-$ \\
\hline Rak & 166.667,-- & $146.667,-$ & $20.000,-$ \\
\hline $\begin{array}{l}\text { Biay a Pemeliharaan } \\
\text { Mesin dan Peralatan }\end{array}$ & $150.000,-$ & $132.000,-$ & $18.000,-$ \\
\hline Total & $15.415 .450,-$ & 13.275.320,- & $2.140 .130,-$ \\
\hline
\end{tabular}

\title{
4. Harga Pokok Produksi Metode Full Costing
}

Harga pokok produksi untuk roti tawar dengan menggunakan metode full costing sebesar Rp.4.322,- dimana hasil ini didapatkan dari total biaya produksi untuk roti tawar sebesar Rp.91.023.897,-- dibagi dengan jumlah produksi roti tawar sebulan 21.060 pcs. Adapun harga pokok produksi untuk roti manis sebesar Rp.5.158,- dimana hasil ini juga di dapatkan dari total biaya produksi untuk roti manis sebulan sebesar Rp.14.483.117,- dibagi dengan jumlan produksi roti manis sebulan 2.808 pcs.

\section{Laporan Harga Pokok Produksi dengan Metode Full Costing}

\author{
Tabel 11. Laporan HPP \\ Roti Tawar \\ CV. Taeng Jaya Mandiri \\ Metode Full Costing
}




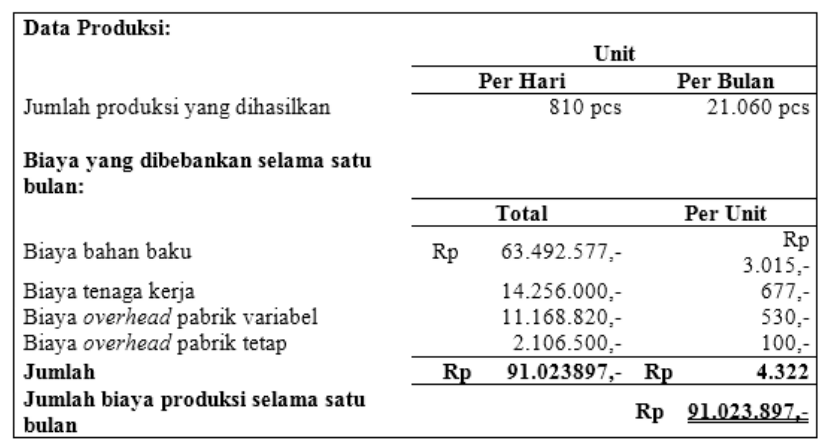

Sumber: Data diolah

Tabel. 12. Laporan HPP Roti Manis CV. Taeng Jaya Mandiri Metode Full Costing

\begin{tabular}{|c|c|c|c|}
\hline \multirow[t]{2}{*}{ Data Produksi: } & \multicolumn{3}{|c|}{ Unit } \\
\hline & & Per Hari & Per Bulan \\
\hline Jumlah produksi yang dihasilkan & & $108 \mathrm{pcs}$ & $2.808 \mathrm{pcs}$ \\
\hline \multicolumn{4}{|l|}{$\begin{array}{l}\text { Biaya yang dibebankan selama satu } \\
\text { bulan: }\end{array}$} \\
\hline \multirow[b]{2}{*}{ Biaya bahan baku } & & Total & Per Unit \\
\hline & & $\begin{array}{r}\mathrm{Rp} \\
\end{array}$ & Rp \\
\hline \multirow{5}{*}{$\begin{array}{l}\text { Biaya tenaga kerja } \\
\text { Biaya overhead pabrik variabel } \\
\text { Biaya overhead pabrik tetap } \\
\text { Jumlah } \\
\text { Jumlah biaya produksi selama satu } \\
\text { bulan }\end{array}$} & & $1.944 .000=-$ & 692,- \\
\hline & & $1.852 .880,-$ & $659,-$ \\
\hline & & $287.250,-$ & $103,-$ \\
\hline & $\mathrm{Rp}$ & 14.483.117,- Rp & $5.158,-$ \\
\hline & & Rp & $\underline{14.483 .117}$ : \\
\hline
\end{tabular}

Sumber: Data diolah

\section{Perbandingan Harga Pokok Produksi menurut Perusahaan dengan Metode Full Costing}

Tabel 13

Perbandingan Harga Pokok Produksi Metode Perusahaan dengan Metode Full costing

\begin{tabular}{|c|c|c|c|c|c|c|}
\hline Biaya Produksi & \multicolumn{2}{|c|}{ Perusahaan } & \multicolumn{2}{|c|}{ Full costing } & \multicolumn{2}{|c|}{ Selisih } \\
\hline Tenaga Kerja & 33.390.000,- & 33.390.000,- & 14.256.000,- & 1.944.000,- & 19.134.000, & 31.446.000,- \\
\hline Total & 119.606.000,- & 133.204.000, & 91.023.897,- & 14.483.117, & 28.582 .103 & 118.72.883,- \\
\hline Jumlah Produksi (pes) & 26.000,- & 26.000,- & 21.060,- & 2.808,- & 4.940,- & 23.192,- \\
\hline HPP per pes & 4.600,- & 5.123,- & 4.322,- & 5.158,- & 278 & -35 ,- \\
\hline
\end{tabular}

Sumber: Data diolah

Dari tabel 13, dapat dilihat selisih harga pokok produksi sebesar Rp 278,- per pcs untuk roti tawar dan $\mathrm{Rp}-35,-$ untuk roti manis.

Setelah melakukan olah data terkait dengan perhitungan harga pokok produksi yang dilakukan oleh perusahaan dengan perhitungan harga pokok produksi dengan 
menggunakan metode full costing terdapat beberapa perbedaan dikarenakan beberapa hal :

1. Untuk biaya bahan baku, perhitungan perusahaan lebih besar dibandingkan dengan metode full costing, hal ini disebabkan karena perusahaan menghitung produksi roti setiap harinya itu sebanyak 1.000 pcs untuk setiap jenis roti, tetapi kenyataannya produksi yang dilakukan setiap hari adalah \pm 1000 pcs untuk kedua jenis roti tersebut dimana untuk roti manis 810 pcs dan untuk roti tawar 108 pcs.

2. Untuk biaya tenaga kerja juga terdapat perbedaan antara perhitungan menurut perusahaan dan perhitungan menggunakan metode full costing dimana perbedaan tersebut disebabkan oleh adanya biaya yang bukan merupakan biaya tenaga kerja tetapi digolongkan ke dalam biaya tenaga kerja, misalnya biaya operasional kendaraan dan biaya catering. Adapun biaya tenaga packing yang seharusnya dimasukkan kedalam biaya tenaga kerja langsung, tetapi perusahaan tidak memperhitungkannya. Kemudian perusahaan juga tidak mengalokasikan total biaya tenaga kerja sesuai dengan jumlah produksi yang sesungguhnya. Sebaliknya perusahaan menghitung kalau jumlah biaya tenaga kerja tersebut untuk setiap jenis roti yang di produksi. Hal inilah yang menyebabkan perhitungan biaya tenaga kerja oleh perusahaan sangat tinggi dibandingkan dengan biaya tenaga kerja menurut perhitungan secara full costing.

3. Pada biaya overhead pabrik juga terjadi perbedaan jumlah antara perusahaan dengan perhitungan menurut metode full costing. Perbedaan ini disebabkan adanya biaya - biaya yang tidak diperhitungkan oleh perusahaan untuk digolongkan kedalam biaya overhead pabrik. Seperti, biaya penyusutan mesin dan peralatan serta biaya pemeliharaan mesin dan peralatan, dimana pada perhitungan menurut metode full costing, kedua biaya tersebut dimasukkan kedalam biaya overhead pabrik. Adapun perbedaan pencatatan yang lain juga terdapat pada perhitungan total biaya overhead pabrik dimana perusahaan juga tidak mengalokasikannya sesuai dengan jumlah produksi yang sebenarnya.

\section{PENUTUP \\ Simpulan}

Berdasarkan hasil perhitungan, terdapat perbedaan antara metode yang digunakan perusahaan dengan metode full costing. Hal ini disebabkan karena dalam penerapan harga pokok produksi, perusahaan masih menggunakan cara sederhana dan beberapa biaya dihitung berdasarkan estimasi, perbedaan juga terdapat pada pembebanan biaya sejak awal produksi. Metode perusahaan tidak memperhitungkan biaya overhead pabrik tetap ke dalam biaya produksi, sedangkan metode full costing memperhitungkan seluruh biaya baik yang berperilaku variabel maupun tetap.

\section{Saran}

Perusahaan sebaiknya menerapkan metode full costing dalam menetapkan harga pokok produksi dengan cara memperhitungkan seluruh biaya produksi meliputi biaya bahan baku, biaya tenaga kerja, dan biaya overhead pabrik, dan mengklasifikasikannya secara tepat sehingga perhitungan harga pokok produksi menggambarkan total biaya produksi yang sesungguhnya yang lebih akurat sebagai dasar dalam menetapkan harga jual yang tepat. 


\section{UCAPAN TERIMA KASIH}

Penulis mengucapkan terima kasih kepada seluruh pihak yang telah membantu dalam penelitian ini. Utamanya kepada Pimpinan Pabrik Roti Taeng yang telah memberikan kesempatan kepada penulis untuk meneliti di UMKM tersebut.

\section{DAFTAR PUSTAKA}

Bustami dan Nurlela. (2013). Akuntansi Biaya. Jakarta. Penerbit Mitra Wacana Media.

Dewi ,Sofia P. dan Kristanto ,Septian B. (2017). Akuntansi Biaya, Edisi 2. Bogor. Penerbit In Media.

Hansen dan Mowen. (2013) . Akuntansi Manajerial (Managerial Accounting). Jakarta. Salemba Empat.

Mulyadi. (2014). Akuntansi Biaya, Edisi ke-5. Yogyakarta. UPPM-STIM YKPN.

Sugiyono. (2017). Metode Penelitian Bisnis. Bandung. Alfabeta

Sujarweni, V. Wiratna. (2015). Akuntansi Biaya. Yogyakarta. Pustaka Baru Press. 